\title{
THE ANALOGY BETWEEN NATURAL PERSONS AND INTERNATIONAL PERSONS IN THE LAW OF NATIONS
}

I

INFLUENCE OF THE ANALOGY UPON THE CIASSICAI WRITERS ON THE LAW OF NATIONS

The analogy between natural persons and international persons was one of the main premises upon which the science of international law was founded in the sixteenth and seventeenth centuries. It was assumed that there existed a close resemblance, for many purposes, between the legal rights and duties of natural persons, subjects of municipal law, and the rights and duties of those juristic persons which are the subjects of international law. In one form or another the analogy was invoked constantly from the time when the law of nations first became a subject of juristic speculation and practical significance. The early conceptions of the nature of international society were based upon it. It furnished one of the essential premises in that process of reasoning by which the law of nature was applied to nations. It justified wholesale borrowing from the Roman jus gentium. It has had an immeasurable influence upon the subsequent development of international law, having been appealed to in later years as a reason for transplanting into the law of nations many concepts, principles, and rules borrowed outright from various systems of municipal law.

An examination of the writings of the great publicists, particularly those of the seventeenth and eighteenth centuries, reveals something of the extent to which we are indebted to this analogy for almost everything that is regarded as fundamental in modern international law. Such a study shows that the analogy has had a significant influence in contributing to determine (I) our conception of the nature of international society, (2) our conception of the nature of the persons who compose that society, (3) our conception of the nature of the law applicable to that society, (4) the actual content of that law, and (5) the classification of the content of that law.

It may be objected by members of a profession trained to look for law primarily in sources other than text-books and treatises 
that conclusions based upon a study of the writers must have a somewhat limited significance. We must remember, however, that the sources of international law have never included much that can be compared to statutes and judicial precedents in municipal law; that international customs are hard to discover and that there is almost no one to discover them but the writers; and that in consequence the opinions of experts have been easily the most authoritative source of international law. Statesmen have always referred to the treatises of the great publicists as authoritative sources of the highest value. The Supreme Court of the United States, in the case of The Paquete Habana and The Lola, has said:

"where there is no treaty, and no controlling executive or legislative act or judicial decision, resort must be had to the customs and usages of civilized nations; and, as evidence of these, to the works of jurists and commentators who by years of labor, research and experience, have made themselves peculiarly well acquainted with the subjects of which they treat. Such works are resorted to by judicial tribunals, not for the speculations of their authors concerning what the law ought to be, but for trustworthy evidence of what the law really is."

Kent says that

"in cases where the principal jurists agree, the presumption will be very great in favor of the solidity of their maxims; and no civilized nation, that does not arrogantly set all ordinary law and justice at defiance, will venture to disregard the uniform sense of the established writers on international law."

The opinions of writers have had a much greater influence upon the development of the law of nations than upon the development of any system of municipal law. In international law, therefore, we shall be obliged to attach an unwonted significance to conclusions supported by the testimony of all the leading publicists.

With these preliminary observations let us turn our attention for a brief space to the influence of the analogy between natural persons and international persons upon the system developed by the great writers of the sixteenth, seventeenth, and eighteenth

${ }^{1}$ (1900) I75 U. S. 677,700 . Cf. the language of Lord Coleridge in The Queen v. Keyn (1876) 2 Ex. D. 63.

${ }^{2}$ Commentaries, Vol. I, pp. I8-19. 
centuries. It will not be possible to dwell at length upon their indebtedness to the analogy for the content of their treatises and for the principles of classification which they adopted. Some illustrations can be given, however, and something can be said of the analogy's influence upon the fundamental conceptions of the science.

After the Reformation the old theory of a common superior decayed, due to the inability of either Emperor or Pope to command universal obedience. The conception of a society of independent states supplanted the idea of universal empire. It fell to the lot of the early publicists to find an explanation for this society, its members, and its law. It was their task also to discover the content of this new body of law and to classify it. They derived the law applicable to the relations between independent states from two sources. In the first place, finding some rules already in existence, especially in connection with diplomacy and warfare, they referred to established customs, usages, and understandings. Finding that large parts of the field of international relations were not covered by established custom, they sought a more general and permanent basis whereon to build up a system of positive rules. They recurred, in the second place, to the law of nature, a law grounded on reason and valid for all mankind, and applied it to the relations between independent states. $^{3}$ As Sir Henry Maine has said:

${ }^{3}$ On the use which the early writers made of the law of nature, see Bryce, Studies in History and Jurisprudence (New York, IgoI) Vol. II, pp. 602-604; Hicks, The Equality of States and The Hague Conferences (I908) 2 AM. Jour. INT. LAw, 530-56I, $53 \mathrm{I}$ ff.; Lawrence, Essays on Some Disputed Questions (London, I884) p. I85; Maine, Ancient Law (4th Am. from Ioth London ed., New York, 1906) pp. 92 ff.; Nys, Les origines du droit international (Paris, I894) p. 8.

On the law of nature generally, see also Brini, Jus Naturale (Bologna, I889); Carlyle, History of Mediaeval Political Theory in the West (London, 1903-rgr5); Dunning, Fistory of Political Theories (New York, I902-1905); Hély, Etude sur le droit de la guerre de Grotius (Paris, I875) pp. $207 \mathrm{ff}$; Holland, Elements of Jurisprudence (roth ed., New York, I906) pp. 30-38; Hunter, Roman Law (3d ed., London, I897); Muirhead, Law of Rome (2d ed., London, 1899); Phillipson, International Law and Custom of Ancient Greece and Rome (London, IgrI); Pollock, History of the Law of Nature (IgO0) 2 Jour. Soc. CoMp. LEG. (N. S.) 4I8-433; Ritchie, Natural Rights (London, I903); Vaunois, De la notion du droit naturel chez les Romains (Paris, I884); Voigt, Das jus naturale aequum et bonum und jus gentium der Römer (Leipzig, 1856-1876); Walker, History of the Law of Nations (Cambridge, I899); Haines, The Law of Nature in State and Federal Judicial Decisions (I9I6) 25 YALE LAW
Journal, 6r7. 
"they laid down unreservedly that Natural Law is the code of states, and thus put in operation a process which has continued almost down to our own day, the process of engrafting on the international system rules which are supposed to have been evolved from the unassisted contemplation of the conception of Nature."'

They reasoned that men in a state of nature were controlled by natural law; that since there was no common superior to control the relation of international persons they must be in a state of nature with respect to each other; and that by analogy with men in a state of nature international persons must be controlled by natural law. The writers made a twofold use of this law of nature. From the theoretical natural law expounded by the philosophers they borrowed conceptions, by means of the analogy, which helped them to explain international society and the law applicable thereto. But there was another and a more substantial kind of natural law. At Rome the notion of nature as a source of law had passed from philosophy into legal thought. The jus naturale had become closely identified with the jus gentium, a system of private law which was supposed to be founded on natural reason and to exist among many peoples.5 From the jus gentium, regarded as a natural code, the writers derived a large body of practical rules, as well as principles of classification, which they incorporated into the international system.

This tendency to draw upot the theory and content of municipal law, upon the assumption that an analogy exists between natural persons and international persons, appears in the treatises of the forerunners of Grotius, including Victoria (I480-I546), Vasquez (I509-I566), Ayala (I548-I 584), Suarez (I548-I6I7), and Gentilis (I552-I608). ${ }^{B}$

'Op. cit., p. 96.

'Dig., i, I, I, 4; Gaius, Inst., i, I.

-Victoria, Relectiones undecim (Salamanca, 1565). First published at Lyons in 1557. See Barthélemy in Les fondateurs du droit international (Paris, I904) pp. 1-36; and Walker, op. cit., pp. 214-230.

Vasquez, Controversiarnm illustrium (Venice, 1564). See Walker, op. cit., pp. 245-246 and passim.

Ayala, De Jure et Officiis Bellicis et Disciplina Militari, in The Classics of International Law, published by the Carnegie Institution of Washington (Washington, Igr2). First published at Douay in 1582. See Walker, op. cit., pp. 247-249.

Suarez, Tractatus de legibus (Mayence, I6Ig). First published at Coim- 
It is more conspicuous in the De Jure Belli ac Pacis ${ }^{7}$ of Grotius ( $1583-1645)$. While Grotius does not elaborate in a systematic way upon those subtle comparisons by which later writers explain the nature of international society and international law, he does dwell occasionally upon the natural condition of mankind ${ }^{8}$ and make occasional use of an analogy between men in a state of nature and international persons uncontrolled by superior authority. ${ }^{\circ}$ He relies frequently upon the analogy between natural and international persons to support the rules laid down. "And these artificial bodies have plainly an analogy with natural bodies," he says. $^{10}$ His reliance is explicit where he compares the ruler of a state to the master of a family, ${ }^{11}$ clients under the protection of patrons to international persons protected by an unequal alliance, ${ }^{12}$ and natural persons reduced to slavery to international persons reduced by conquest. ${ }^{13}$ It appears also in what he says of diseased states, ${ }^{14}$ and in what he says of the right of states, analogous to the right of individuals out of society, to punish grievous violations of the law of nature or of nations, although

bra in I6r2. See Dunning, op. cit., Vol. II, pp. I35-I49; Rolland in Les fondateurs, pp. 95-124; and Walker, op. cit., pp. 155-156.

Gentilis, De legationibus (Hanover, $\mathrm{I}_{594}$ ); De jure belli (Holland's ed., Oxford, 1877); and Hispanicae advocationis (Amsterdam, r76 1 ). First published at London in $1585,1588-89$, and 1613 respectively. See Holland, Studies in International Law (Oxford, I8g8) pp. I-39; Nézard in Les fondateurs, pp. 37-93; Phillipson in Great Jurists of the World (Boston, IgI4) pp. I09-I43; and Walker, op. cit., pp. 249-276.

${ }^{7} \mathrm{I}$ have consulted the reproduction of the edition of 1646 in The Classics of International Law (Washington, 19I3), the French translation of Pradier-Fodéré (Paris, 1867), and Whewell's edition (Cambridge, 1853).

Among secondary works, see Basdevant in Les fondateurs, pp. 125-267; Dunning, op. cit., Vol. II, chap. 5; Hallam, Introduction to the Literature of Europe (New York, I859) Vol. II, pp. I4I-I62; Hély, op. cit.; Lawrence, op. cit., Essay IV; Rattigan in Great Jurists of the World, 'pp. I69-I84; Walker, op. cit., pp. 278-337; White, Seven Great Statesmen (New York, rgIo) pp. 55-IIO.

${ }^{8} \mathrm{I}$, iv, 7, 3 ; I, v, I; II, ii, 2; II, $\mathrm{x}, \mathrm{I}, 2$; II, $\mathrm{xx}, 8-9$; II, $\mathrm{xx}, 40, \mathrm{I}-4$; and III, vii, I, I.

${ }^{\circ}$ II, xi, 5, 3; II, xx, 40.

${ }^{10}$ Plane autem corpora haec artificialia instar habent corporis naturalis. II, ix, 3, I.

${ }^{12} \mathrm{I}, \mathrm{iii}, \mathrm{I} 6, \mathrm{I}$.

${ }^{12} \mathrm{I}, \mathrm{iii}, 2 \mathrm{r}$.

${ }^{23}$ II, xxi, 7, 2; III, viii, I-4.

14 III, iii, $2,2$. 
they themselves may not have suffered immediate injury. ${ }^{15} \mathrm{He}$ carries the analogy to an absurd extreme when he tells us that there are evidently as many sources of war as there are of actions at law. ${ }^{16}$ Passages like the above illustrate the use which Grotius makes of the analogy, but they hardly suggest the importance of his indebtedness to municipal law. His work bristles with borrowings. The atmosphere of legal science in his day was an atmosphere of Roman law. In the jus gentium he had an unfailing supply of principles, and he used it unsparingly. He borrows from it whole categories of rules relating to property, contracts, and other topics. His classification is based upon the divisions of municipal law, as a mere reading of his table of contents will reveal. It was this borrowed element that assured the permanence of his system. "The system of Grotius lived because it was grafted on a living tree."17

Among the successors of Grotius three tendencies appeared, represented by the naturalists, the positivists, and the Grotians respectively. The naturalists held that the so-called law of nations was nothing more than the law of nature applied to the society of international persons; and they accordingly denied to the positive, customary, or conventional element the character of real law apart from the natural law. The positivists contended that the principles underlying customs and treaties constituted a positive international law distinct from the natural law and of superior practical importance. The Grotians took an intermediate position, retaining Grotius' distinction between the natural law and the positive or voluntary law of nations, but unlike Grotius treating the two as of equal importance. ${ }^{18}$

The naturalists made an unsparing use of the analogy between natural and international persons, both to explain international

\footnotetext{
${ }^{15} \mathrm{II}, \mathrm{xx}, 40$.

${ }^{10}$ II, i, 2, I.

sT “. . . made known by generations of mediaeval legal thinkers, the principles of pure Roman Civil Law yet spoke in the day of Grotius with the authority of lex scripta. The obligatory force which men acknowledged in these principles as rules of a municipal legal system was accorded them when they were enunciated as laws of international conduct. The system of Grotius lived because it was grafted on a living tree." Walker, op. cit., pp. 334-335.

${ }^{13}$ Hély, op. cit., pp. 22I-222; Hershey, Essentials of International Public Law (New York, I9I4) pp. 59-63; Phillipson in Great Jurists of the World, p. 394.
} 
society, the persons included therein, and the law applicable thereto, and also to justify copious borrowings from municipal law, principally of course from the Roman jus gentium. The use made of the analogy by the positivists was only a little less obvious. They placed less emphasis upon an analogy between states and men in a state of nature, and upon natural rights, and more emphasis upon the development of international law through custom founded on consent. Their understanding of consent, its nature and effect, was determined by recourse to principles of municipal law. They drew freely from municipal law wherever there was insufficient evidence of established international practice or agreement. It remained for the Grotians to discover that the analogy between natural and international persons had been abused, and that natural law ought to be adapted, when applied to international persons, to the nature of its new subjects. Their discovery was a significant one, but unfortunately it seems to have influenced the theory of international law more than the substance. We can refer briefly to only a few of the leading representatives of each of these three tendencies.

The bias of the naturalists was largely determined by a writer who touched upon the law of nations only incidentally, and whose influence upon the subsequent development of the science is all too little appreciated. In his $D e$ Cive and Leviathan, ${ }^{19}$ Hobbes (I588-1679) revived for the purposes of juridical philosophy the whole mediaeval theory of natural law and the state of nature. Hobbes draws a close analogy between man and the state, ${ }^{20}$ and

${ }^{10}$ Elementa Philosophica de Cive (Amsterdam, I657); and Leviathan, Waller's ed. in Cambridge English Classics (Cambridge, 1904). The former was first published in 1642, and the latter in I651. See de Montmorency in Great Jurists of the World, pp. 195-219.

${ }^{20}$ Hobbes introduced his Leviathan with the following passage: "For by ART is created that great LEVIATHAN called a COMMONWEALTH, or STATE, (in latine CIVITAS) which is but an Artificiall Man; though of greater stature and strength than the Naturall, for whose protection and defense it was intended; and in which, the Soveraignty is an Artificiall Soul, as giving life and motion to the whole body; The Magistrates, and other Officers of Judicature and Execution, artificiall Joynts; Reward and Punishnent (by which fastned to the seate of the Soveraignty, every joynt and member is moved to performe his duty) are the Nerves, that do the same in the Body Naturall; The Wealth and Riches of all the particular members, are the Sirength; Salus Populi (the people's safety) its Businesse; Counsellors, by whom all things needfull for it to know, are suggested unto it, are the Memory; Equity and 
contends that states stand to one another in the same relation that existed between men in the state of nature. ${ }^{21} \mathrm{He}$ concludes that the law of nature and the law of nations are the same thing, the latter consisting simply in the application of the former to the society of independent states. ${ }^{22}$ In I658 Pufendorf (I632-I694) spent eight months in a Danish prison, meditating on what he had read in Hobbes and Grotius. Several years afterward he published his ponderous magnum opus, entitled De Jure Naturae et Gentium, ${ }^{23}$ in which he combined many of the theories of Hobbes with a large part of the practical code elaborated by Grotius. Where Pufendorf differs from Grotius his opinion is usually traceable to the influence of Hobbes. He borrows from Hobbes his conception of the law of nature, his identification of the law of nature and of nations, and his theory of international society. He refutes the Grotian conception of a voluntary or positive law of nations, and subscribes implicitly to the opinion of Hobbes that the law of nations is nothing but the law of nature applied to independent states. ${ }^{24}$ Both are made up of the same precepts, for as soon as they are formed states assume the personal properties of men, and stand in the same relation to each other that prevailed between men in the state of nature. ${ }^{25}$ Pufendorf's work enjoyed an immense success; and for nearly a century a majority of the continental writers on natural law and the law of nations, especially in Germany, acknowledged his leadership. The naturalists, for whom Hobbes was the animating spirit and Pufendorf the leader, drew the content of their system and its principles of classification from municipal law. They derived their fundamental ideas of international persons, international society, and the law of nations

Lawes, an artificiall Reason and Will; Concord, Health; Sedition, Sicknesse; and Civill war, Death. Lastly, the Pacts and Covenants, by which the parts of this Body Politique were at first made, set together, and united, resemble that Fiat, or the Let us make man, pronounced by God in the Creation." Introd. See also Pt. II, chap. xvii.

${ }^{21}$ De Cive, chap. xiii, sec. 7 ; Leviathan, Pt. II, chap. xxx.

${ }^{2}$ De Cive, chap. xiv, sec. 4 ; Leviathan, Pt. II, chaps. xxix and xxx.

${ }^{23}$ First published in 1672 . I have consulted Kennett's English translation (5th ed., London, 1749), and Barbeyrac's French translation (Leyden, 1759). See Avril in Les fondateurs, pp. 33I-383; and Phillipson in Great $J$ urists of the World, pp. 305-344.

${ }^{2}$ II, iii, 23.

${ }^{25}$ II, ii, I ; II, ii, 4; VII, i, 8; VIII, iv, I8; VIII, vi, I; VIII, vi, I2 ; and passim. 
from their implicit belief in the natural law of mankind and in its application by analogy to international persons. Rutherforth (I7I2-I77I), writing in the next century, illustrates their basic idea. He finds an element of consent, giving international law a positive character in its application, in the universal agreement of all nations to recognize the state-personality of each; but he contends that international law is entirely natural in its subjectmatter. If one understands, he says,

"what the law of nature is, when it is applied to individual persons in a state of equality, he will seldom be at a loss to judge what it is, when he is to apply it to nations considered as collective persons in a like state of equality."28

The positive character of international law was emphasized by Rachel $^{27}$ (I628-I69I) and Textor ${ }^{28}$ (I637-ryor). Their treatises were a protest against the naturalist school; and yet, while basing international law primarily upon positive agreement, they stressed the analogy between natural and international persons almost as much as the school of Pufendorf. Rachel says that

"it is by agreement after the manner of private individuals that the Law of Nations is set up by free peoples" and that "by means of that Law they are formed into a Society and are bound to one another."29

The law of nations cannot be wantonly abrogated, Rachel tells us, because

"it is a rule of Civil Law that a society or partnership can not be quitted in any way that savors of fraud ( $D i g$. $17,2,-14)$; and the same rule holds even more in the society of Nations."30

Furthermore,

"if two subjects of the same State have bound themselves by an agreement and one commits a fraud on the agree-

${ }^{29}$ Institutes of the Natural Law (2d Am. ed., Baltimore, 1832) II, ix, 5 and 7. Rutherforth's work was first published in 1754-56.

${ }^{27}$ De Jure Naturae et Gentium Dissertationes, in The Classics of International Law (Washington, I9I6). First published in 1676.

${ }^{2 s}$ Synopsis Juris Gentium, in The Classics of International Law (Washington, I916). First published in I680.

${ }^{\circ}$ De Jure Gentium, secs. 2 and 3.

${ }^{\text {so }}$ Ibid., sec. 88. 
ment, the other can restrain him by judicial authority and obtain redress by action at Law; in just the same way, as there is no common tribunal for free Nations, one of them may, other things being equal, resort to war as a means of compelling another, who has proved perfidious, to carry out what has been agreed on."

These are examples of the more obvious influence of the analogy in Rachel's treatise. Both Rachel and Textor drew heavily from the Roman law. Of a considerable part of Textor's Synopsis Juris Gentium, Professor Ludvig von Bar remarks that it is

"more frequently based on the principles of private law, and therefore does not do justice to the real needs and relations of the Law of Nations." 32

Textor's tendency is well illustrated in what he says about the interpretation of treaties:

"What of the Roman Law? Do its canons of interpretation apply to the public agreements of kings and peoples? If we are speaking of those canons which have the force of Law and bind contracting parties, Grotius is probably right (ch. I6, sec. 3I.) that Roman Law is not to be adopted as a standard any further than the conduct of the peoples of the world show that it is received by them as the Law of Nations. If, however, we understand the question to refer simply to the persuasive and probable aspects of the interpretation of treaties, an affirmative answer is correct although Roman Law is not received as Law, because there is a balance of probability on the side of that king or people who can claim the support of the Roman Law, a system which, by the consent of nearly all mankind, is uniquely just. In this connection we have the remarks of de Thou (preface to his History), that the whole (cultured) world was Roman, so that the legal pronouncements on a case can easily be ascertained by the use of the Roman Law as a Law of Nations."33

Both naturalists and positivists depended extensively upon municipal law for their conceptions, classifications, and rules. This is not surprising, but it is surprising that they defended their dependence as practically and theoretically sound. In theory at least, the Grotians saw the danger in this dogmatic and undiscriminating use of the analogy, and made an effort to cor-

sI Ibid., sec. 9I.

Textor, op. cit., Vol. II, Introd., p. roa.

${ }^{23}$ Chap. xxiv, secs. 29-30. 
rect it. Wolff (1679-I754) is the most illustrious advocate of their point of view. His position is well stated in the preface to his Jus Gentium Methodo Scientifica Pertractatum, ${ }^{34}$ where he says :

"It is true that Nations can only be considered as so many individual persons living together in a state of nature, and therefore all the duties and the rights which nature prescribes and imposes upon all men, in so far as they are by nature born free and are held together only by the ties of nature, should be applied to states as well."

He calls this the natural or necessary law of nations. So far his position is the same as that of the naturalists, but he continues:

"But as Nations or sovereign States are corporate persons and the subjects of obligations and rights which in virtue of the natural law result from the act of association by which political bodies are formed, the nature and essence of these moral persons will necessarily differ in many respects from the nature and essence of the physical units, or men, who compose them. Hence, since rights and duties must be consistent with the nature of their subjects, in applying to Nations the duties which the natural law imposes upon each individual and the rights it confers in order that he may fulfil those duties, they must necessarily be changed so as to suit the nature of the new subjects. Thus it is seen that the Law of Nations is not the same at all points as the natural Law, since the latter controls the actions of individuals."

This was the first explicit recognition by a great publicist of the fundamental defect in the process of building international law upon an analogy between natural and international persons. Wolff's theories were given a wider currency through the work of his brilliant admirer Vattel ${ }^{135}$ (I7I4-I767). Like his great master, Vattel treats the natural or necessary law of nations as a separate science consisting of a just and rational application

\footnotetext{
${ }^{34}$ Published at Frankfort and Leipzig in 1764 . See Olive in Les fondateurs, pp. 447-479.

${ }^{3}$ Le Droit des Gens, ou Principes de la Loi Naturelle, appliqués d̀ la Conduite aux Affaires des Nations et des Souverains, in The Classics of International Law (Washington, 19I6). First published in 1758. See Mallarmé in Les fondateurs, pp. 48I-60r; and Phillipson in Great Jurists of the World, pp. 477-504.
} 
analogy already well entrenched in the literature of the science. The analogy between natural and international persons has continued to be a factor of great significance in the evolution of the law of nations.

It has been invoked repeatedly to explain international society. The more modern view is exemplified in Hall, who says:

"It is postulated by those independent states which are dealt with by international law that they have a moral nature identical with that of individuals, and that with respect to one another they are in the same relation as that in which individuals stand to each other who are subject to law."s8

It accounts for the emphasis placed by a majority of the writers upon the so-called primary, inherent, absolute, inalienable, or fundamental rights of states, rights derived originally from no other source than the fictitious analogy with men controlled by natural law. Take Klüber, ${ }^{39}$ for example, at the beginning of the modern period. His position is similar to that taken by a great many others. ${ }^{40}$ Klüber regards nations as so many persons living in a state of natural liberty. He considers the law of nations as natural so far as it results from the nature of international society, and positive so far as it results from tacit or express convention. ${ }^{41}$ From the nature of inter-

\$International Law (6th ed. by Atlay, Oxford, 1909) p. I7.

${ }^{2}$ Droit des gens moderne de l'Europe (2d French ed. by Ott, Paris, 1874). First published in French in 1819 and in Germąn in 1821.

to "Until the last two decades of the nineteenth century all jurists agreed that the membership of the Family of Nations includes so-called fundamental rights for States. Such rights are chiefly enumerated as the right of existence, of self-preservation, of equality, of independence, of territorial supremacy, of holding and acquiring territory, of intercourse, and of good name and reputation. It was and is maintained that these fundamental rights are a matter of course and self-evident, since the Family of Nations consists of Sovereign States. But no unanimity exists with regard to the number, the names, and the contents of these alieged fundamental rights. A great confusion exists in this matter, and hardly two text-book writers agree in details with regard to. it. This condition of things has led to a searching criticism of the whole matter, and several writers have in consequence thereof asked that the fundamental rights of States should totally disappear from the treatises on the Law of Nations." Oppenhein, International Law (2d ed., London, I912) Vol. I, pp. $165-166$.

${ }^{4}$ Op. cit., sec. 1 . 
analogy already well entrenched in the literature of the science. The analogy between natural and international persons has continued to be a factor of great significance in the evolution of the law of nations.

It has been invoked repeatedly to explain international society. The more modern view is exemplified in Hall, who says:

"It is postulated by those independent states which are dealt with by international law that they have a moral nature identical with that of individuals, and that with respect to one another they are in the same relation as that in which individuals stand to each other who are subject to law."38

It accounts for the emphasis placed by a majority of the writers upon the so-called primary, inherent, absolute, inalienable, or fundamental rights of states, rights derived originally from no other source than the fictitious analogy with men controlled by natural law. Take Klüber, ${ }^{38}$ for example, at the beginning of the modern period. His position is similar to that taken by a great many others. ${ }^{40}$ Klüber regards nations as so many persons living in a state of natural liberty. He considers the law of nations as natural so far as it results from the nature of international society, and positive so far as it results from tacit or express convention. ${ }^{41}$ From the nature of inter-

\$International Law (6th ed. by Atlay, Oxford, 1909) p. I7.

${ }^{29}$ Droit des gens moderne de l'Europe (2d French ed. by Ott, Paris, 1874). First published in French in I8rg and in Germąn in 1821.

40 "Until the last two decades of the nineteenth century all jurists agreed that the membership of the Family of Nations includes so-called fundamental rights for States. Such rights are chiefly enumerated as the right of existence, of self-preservation, of equality, of independence, of territorial supremacy, of holding and acquiring territory, of intercourse, and of good name and reputation. It was and is maintained that these fundamental rights are a matter of course and self-evident, since the Family of Nations consists of Sovereign States. But no unanimity exists with regard to the number, the names, and the contents of these alleged fundamental rights. A great confusion exists in this matter, and hardly two text-book writers agree in details with regard to. it. This condition of things has led to a searching criticism of the whole matter, and several writers have in consequence thereof asked that the fundamental rights of States should totally disappear from the treatises on the Law of Nations." Oppenheim, International Law (2d ed., London, I912) Vol. I, pp. $165-166$.

"Op. cit., sec. 1 . 
national society he concludes that the rights of nations are similar to the rights of men living in a state of natural liberty, and; therefore, that the rights attributed by nature or reason to individuals should in like manner be attributed to independent states. $\mathrm{He}$ finds accordingly that independent states have certain original or natural rights, namely, the rights of self-preservation, of independence, and of equality. ${ }^{42}$ A conclusion, similar in several respects to Kliuber's, was defended not long ago by Mr. Robert Lansing in a paper entitled "The Relation of International Law to Fundamental Rights."

"If the analogy between a community of persons and the community of nations is even in a measure complete," remarks Mr. Lansing, "then a state must possess fundamental rights analogous to the personal rights of life, liberty and property. That it does, I think, may be asserted without hesitation, the analogous fundamental rights being those of existence, independence, and the acquisition and control of possessions." 43

There is a most amazing use of the analogy to bolster up the doctrine of fundamental rights in the recent Declaration of the Rights of Nations formulated and adopted by the American Institute of International Law. ${ }^{44}$ According to this Declaration,

"the municipal law of civilized nations recognizes and protects the right to life, the right to liberty, the right to the pursuit of happiness, as added by the Declaration of Independence of the United States of America, the right to legal equality, the right to property, and the right to the enjoyment of the aforesaid rights"; "these fundamental rights can be stated in terms of international law and applied to the relations of the members of the society of nations, one with another, just as they have been applied in the relations of the citizens or subjects of the states forming the Society of Nations"; and stated in terms of international law they are "the right of the nation to exist and to protect and to conserve its existence; the right of independence and the freedom to develop itself

${ }^{2} O$. cit., secs. $37,38,45$, and 89 .

*American Society for the Judicial Settlement of International Disputes, Proceedings (I9I2) pp. 228-243, 232.

"For the text of the Declaration see (IgI6) Io Am. Jour. INT. LAw, 124; and (Jan. 24, 1916) THe New York TrMes. See also Root (1916) Io AMr. Jour. INT. LAW, 2II-22I; and my criticism of the Declaration in (I916) 6 THE NeW REPUBLIC, 9I. 
without interference or control from other nations; the right of equality in law and before law; the right to territory within defined boundaries and to exclusive jurisdiction therein; and the right to the observance of these fundamental rights." 45

It is expressly stated that the right to exist

"is to be understood in the sense in which the right to life is understood in national law, according to which it is unlawful for a human being to take human life unless it be necessary so to do in self-defense against an unlawful attack threatening the life of the party unlawfully attacked."

The analogy between natural and international persons explains a large part of the content of the law of nations. Those principles which refer to dominion, its nature, limitations, and the modes of acquiring and securing it, are pure Roman property law transcribed from the jus gentium. ${ }^{48}$ Rules relating to the obligations arising from treaties and to treaty interpretation are derived largely from a similar source. ${ }^{47}$ Rights incidental to the navigation of international rivers are based upon Roman law principles by the same reasoning. ${ }^{48}$ The rule of the jus gentium forbidding private property in the $\operatorname{sea}^{49}$ has been invoked in support of the freedom of the seas. Happily the analogy was not pressed too far in this instance; the Roman rule, if applied without qualification, would have denied jurisdiction over territorial seas no less than over the open sea.50

Undiscriminating reliance upon the analogy has engrafted a great many unsound principles and impractical rules into the international system. The process of borrowing from Roman property law has obscured the distinction between jurisdiction and property, the former having been described by many writers as a right to property. Attention has been fixed on the points

${ }^{4} \mathrm{~A}$ distinguished authority on international relations is said to have remarked that the Declaration of the Rights of Nations reminded him of the fakir who sold pills which he claimed were "good for earthquakes."

${ }^{48}$ Grotius, op. cit., II, i-x; Maine, op. cit., pp. 97-98.

"Grotius, op. cit., II, xi-xvi.

"Wheaton, Elements of International Law (8th ed. by Dana, Boston, I866) sec. $\mathrm{x} 94$.

Institutes of Justinian (trans. Moyle, Oxford, Igr3) II, i, I-5.

${ }^{\text {so }}$ Westlake, International Law (2d ed., Cambridge, I9I0-13), Vol. I, p. 164 . 
of resemblance rather than upon the essential differences, and it is only among modern writers that the importance of bringing the differences into full relief has been appreciated. ${ }^{51}$ There has been a similar confusion of ideas with reference to international leases, usually alienations disguised in order to spare the susceptibility of the state at whose cost they are made. ${ }^{.2}$ Grotius borrowed the Roman idea of succession on death and adopted it without modification as the principle of state succession. ${ }^{53}$ His error has been corrected, but the heritage of confusion has not been easily cleared away..$^{54}$ Attempts to borrow from the Roman law of contracts, persons, private wrongs, and public wrongs have been equally confusing in many instances. It is unnecessary to multiply illustrations. ${ }^{55}$

Historically speaking the Roman law is the actual basis for the law of nations. From its rich treasury the deficiencies of international precedent, usage, and express authority have been supplied. ${ }^{58}$

"Westlake, op. cit., Vol. I, pp. 88-go.

Ibid., Vol. I, pp. 135-136.

$\bowtie \mathrm{II}, \mathrm{ix}, \mathrm{I2}$.

"Huber, Die Staaten-Succession (Leipzig, I898).

${ }^{\infty}$ There is an interesting illustration of the influence of municipal law upon the growth of international law in the Anglo-American doctrine of domicile as a test of hostile character. Westlake remarks that "it can scarcely be doubted that it is in some degree referable to the fact that in England the admiralty judges have usually been also the judges in probate and matrimonial matters, accustomed in the latter capacity to apply domicile as a criterion, and to rely on old jurists in whose language domicile and nationality were confounded." $O p$. cit., Vol. I, p. 213.

Confusion wrought by the careless use of doubtful analogies has not been confined to international law. It is an all too familiar experience in municipal law. Constitutional law in the United States affords some examples, notably in such matters as the right of corporations to sue in the federal courts [Gray, Nature and Sources of the Law (New York, 1909) secs. 386-390]; and the constructions placed upon the clause forbidding impairment of the obligation of contracts.

${ }^{20}$ Nys, Le droit international (Paris, 1912), Vol. I, pp. 206-212; Phillimore, Commentaries Upon International Law (3d ed., London, I879-1889) Vol. I, pp. 30-37.

Phillimore says: "Independently of the historical value of the Roman Law as explanatory of the terms and sense of treaties, and of the language of jurists, its importance as a repository of decisions, the spirit of which almost always, and the letter of which very frequently, is applicable to the controversies of independent States, can scarcely be overstated." 
"Indeed," says Halleck, "the greater number of controversies between states would find a just solution in this comprehensive system of practical equity, which furnishes principles of universal jurisprudence ipplicable alike to individuals and to states." 57

Maine declares that, aside from the positive or conventional law of nations, it is surprising how large a part of the system is made up of pure Roman law, and astonishing how small a proportion the additions made to international law since Grotius' day bear to the ingredients which have been simply taken from the most ancient stratum of the Roman jus gentium. ${ }^{58}$ And Pollock asserts that the distinctly legal conceptions of the modern law of nations are Roman and purely Roman. ${ }^{59}$

The generous principles of the jus gentium commended it to many peoples, but it is of course a mere truism to say that its principles were never designed for international persons. It was always a system of municipal law. Its extraordinary usefulness should not blind us to the deficiencies in the international system which resulted from utilizing its content without adequate discrimination. These deficiencies should not only be corrected, they should serve as a warning against permitting the analogy between natural and international persons to introduce further confusion into the law of nations. It is difficult to see much advantage in such analogies as those suggested by Holland, for example, between partially dependent states and infancy, coverture, or tutelage, and between the obligations of neutrality and prohibitions of champerty, maintenance, or interference with the course of criminal justice. ${ }^{00}$ It is certainly folly to repeat Zouch's description of warfare as "the litigation of nations."

The analogy is at the foundation of most of our accepted classifications in international law. According to Holland,

"the Law of Nations is but private law 'writ large.' It is an application to political communities of those legal ideas which were originally applied to the relations of individuals. Its leading distinctions are therefore naturally those with which Private Law has long ago rendered us familiar." 61

${ }^{n}$ International Law (New York, I861) p. 55.

"Op. cit., pp. 93, 97.

${ }^{50}$ Maine, op. cit., p. 410, note on The Origins of the Modern Law of Nations.

${ }^{\infty}$ Op. cit., pp. $385,393$.

" Studies in International Law (Oxford, 18g8) pp. I52-I53. 
The analogy's abuse is responsible for a good deal of unsound classification in international law. Systematic divisions borrowed from municipal law have usually proved to be ill-suited to the international system. Where the writers have departed from familiar principles of municipal classification it has too often been to arrange the content of their treatises with reference to the so-called fundamental rights of nations, rights which are mere corollaries resulting from the conception of the independent state as an artificial person, and which ought to be discussed, if at all, under the law of status.

\section{III}

\section{CRITICISM OF THE ANALOGY}

The analogy has not escaped criticism among modern writers. Westlake says of the alleged inherent rights of states that

"it is a logical error to assume, because states are moral persons and therefore capable of rights equally with natural individuals, that they must have the same rights as natural individuals."

It is surprising, however, that the analogy has not been challenged more frequently and with greater effect. So far as the present writer is aware it has never been subjected to a thoroughly critical analysis upon its merits. The question of its intrinsic rightness has usually been evaded by resort to qualifications and other refinements of reasoning.

There are some reasons for this evasiveness which must appeal to us as grounded in common sense. It is undoubtedly true, for example, that the jurists have been able, by borrowing from familiar systems of municipal law, to keep the law of nations abreast with the advancing needs of humanity without the appearance of radical change that arouses conservative opposition. It is also true that the analogy has made it easier to give precision and content to a subject that has been in constant danger of being lost in nebulous speculation. There are other reasons for the analogy's persistence which are harder to justify. The analogy has been regarded as axiomatic. Early writers were accustomed to speak with an air of dogmatic finality, the spell of which, in some instances, has never been broken. The premise under dis-

op. cit., Vol. I, p. 307. 
cussion is an illustration. The analogy is the very foundation for several important principles of international law. If profane hands should be laid upon it some sacred pillars of the international edifice might come toppling down. This circumstance encourages a leniently uncritical attitude. Finally, the analogy has provided jurists trained in the various systems of municipal law with a convenient substitute for originality. Want of originality may be pardoned in Grotius and the early publicists who lived in a world almost devoid of international system. They met humanity's need by drawing from the law of nature and from the systems of national law with which they were familiar. But surely it cannot be said that writers of the present day are similarly excusable, with the record of almost three centuries of the Grotian system open for their enlightenment.. It would seem, as I have remarked elsewhere, that those who persist in the twentieth century in reciting the ancient dogmatic analogies between the rights of human beings and the rights of nations are suffering from a dearth of ideas.

There may be comfortable reasons in normal times for not tampering with the premises of international law. These are not normal times. The international system is in the crucible of barbaric strife. Its reconstruction will call for vastly more than the mere restoration of what has been destroyed. There will be need for new concepts and the elaboration of new principles. Constructive criticism should not be restricted to the content of international law. There should be a revaluation of premises, and among them of the analogy between natural and international persons. If we remain indifferent to this necessity we shall be placed inevitably in a false position. We shall be called to the defense of principles founded upon false postulates. We may find ourselves asserting the soundness of conclusions while refusing to argue the validity of premises. Our position is certain to prove untenable; and international law will be in danger of becoming divorced more than ever from international realities.

A revaluation of the analogy would be a distirict contribution to the much needed adjustment between international law and the world in which we live. It would place less emphasis upon fictitious resemblances and more upon inherent differences. The analogy's defects are obvious if we consider the precise comparison which it involves. By natural persons we mean living human beings, the subjects of municipal law. By international 
persons we mean those independent, organized entities whose rights and duties form the subject-matter of international law. They are sometimes described as artificial entities. ${ }^{63}$ It is convenient for many purposes to think of the international person as an artificial person, but we must not make the mistake of thinking that it can have rights and duties wholly unaffected by the nature of its essential elements. A comparison of the elements essential to the existence of a natural person with the elements generally considered essential to the existence of an international person brings into striking relief some of the fundamental difficulties involved in an analogy between the two.

The first element essential to the existence of an international person is its population. ${ }^{64}$ This element admits of a variety of differences for which there are no satisfactory parallels in a society of natural persons. Among human beings there is an approximation to uniformity in the physical constituents of life, while among states there is the greatest diversity. There is diversity in respect to numbers, ranging all the way from Andorra's 6,000, Panama's 427,000 , or Montenegro's 520,000, to $175,000,000$ in Russia, and more than $437,000,000$ in the British Empire. There is diversity in respect to quality. Before the outbreak of the present war Belgium had a population about the same as that of Abyssinia, and Sweden a population approximately equal to that of Siam, but the differences between these countries resulting from differences in the quality of their populations were too evident to require emphasis. From the population arise the peculiar problems of nationality and alienage, including control over nationals abroad, admission of aliens to the territory, treatment of aliens in the territory, determination of nationality, naturalization and expatriation, and the status of subject races. The distribution of the population within a country, its unity or diversity in respect to race and nationality, its separation into classes based on birth, wealth, or occupation, and its capacity

* Gray defines the state as "an artificial person created in order that, by assuming it as the entity whose organs are the men engaged in protecting a mass of human beings from external and internal fraud and violence, a unity of operation may be given to those organs." Op. cit., sec. I49.

a There is a brief discussion of the essential elements of the state, together with references to more exhaustive treatments of the subject, in Garner, Introduction to Political Science (New York, 1910) chap. 3. See also Hall, op. cit., Pt. I, chap. I. 
for political, economic, or military organization, are factors causing the most extreme diversity among international persons.

The second element essential to the existence of an international person is its territory; and here again we find striking differences in international society for which there are no analogues in the relations of human beings. Natural persons have a power of locomotion and enjoy great freedom of movement, while the element of territory makes the international person immovable. Differences in the area of territory are as significant as differences in population. There are 8 square miles in Monaco, xo,000 square miles in Hayti, more than 3,000,000 square miles in Brazil, and more than $13,000,000$ square miles in the British Empire. Differences in the quality of territory are equally striking. Ecuador's II6,000 square miles of territory and Norway's 124,000 square miles furnish physical bases for quite different types of civilization. Differences in geographic situation with respect to climatic conditions, access to the sea, natural boundaries, and geographic unity are all factors that produce diversities peculiar to international persons. The publicist who minimizes these differences in the attempt to reduce international persons to a common character outrages the realities of international relations quite as much as the American diplomat who is reported to have invited the Government of Switzerland to participate in the naval demonstration at the opening of the Panama Canal.

It is also essential to the existence of an international person that there be a political organization or government. The form and the powers of this political organization are determined by the international person's constitution. Now there are diversities among constitutions for which we find no parallels in the aggregate of elements essential to the existence of physical life. So far, at least, as these diversities affect an international person's capacity to participate in international relations they must be recognized by the law of nations. For illustration, no amount of emphasis upon their artificial personality can disguise the fact that international persons differ materially in respect to the scope and exercise of the treaty-making power. Some appear to be without capacity to make certain kinds of treaties at all. With respect to the exercise of the treaty power, the Constitution of the United States requires the approval of one chamber of the legislature for all kinds of treaties, while other constitutions require the approval of both chambers of the legislature 
for all treaties or for certain kinds of treaties only, or leave treaty-making entirely to the executive. ${ }^{65}$ There are somewhat similar differences among international persons with respect to their capacity to exercise the war power. ${ }^{68}$ Capacity to participate in international relations is qualified also by the kind of internal organization, whether unified, federal, confederate, or real union. Austria-Hungary, composed of the Empire of Austria and the Kingdom of Hungary, each having final authority over its subjects, but neither having separate relations with states outside the composite whole which they form, is not the same kind of international person as unified France, and as a practical matter cannot enjoy precisely the same rights and duties. The British Empire, composed of the United Kingdom, the selfgoverning colonies, crown colonies, protectorates, and spheres of influence is not the same kind of international person as Bulgaria, and no amount of straining at fictions can give the two precisely the same kinds of rights and duties. There is no profit in insisting that the international person is an abstraction and that all abstractions are alike, irrespective of the kind of government represented. Relations are not conducted between abstractions. The ideal or fictitious entity manifests itself only through organs, and these organs may be so limited that there are certain acts they cannot perform, or so that they are constrained to perform the same act in a great variety of ways. ${ }^{67}$ There is no real counterpart for all this among human beings.

The character of an international person depends very intimately upon the character of its system of law, and here again we find a variety of conditions prevailing. There is Chinese Law, Hindu Law, Mohammedan Law, Civil Law, and the Common Law; and the differences between certain of these systems have contributed to produce some of the intricate problems of international law.

Finally, in order that we may have a state in the international sense, there must be some measure of independence, the pre-

\footnotetext{
* Crandall, Treaties, Their Making and Enforcement (2d ed., Washington, 19I6); Michon, Les traités internationaux devant les chambres (Paris, I90r).

${ }^{\infty}$ Constitutional provisions with reference to the war power may be found in Dodd, Modern Constitutions (Chicago, I909) containing the fundamental laws of twenty-two of the most important countries of the world.

" See Gray's discussion of sovereignty in op. cit., secs. $169-183$.
} 
requisite to recognition as an international person. We are coming to see that there are degrees of independence, and that no international person can be said to be absolutely independent unless we are prepared to accept either a world state or universal anarchy. The writers have recognized that differences in the measure of independence enjoyed furnish a legal basis for the recognition of different degrees of status. ${ }^{68}$ As Westlake remarks, "it is not necessary for a state to be independent in order to be a state of international law." tional persons enjoying a normal degree of independence, and below them others in various degrees of dependence, including protectorates, vassal states, neutralized states, members of confederations, communities whose insurgency has been recognized, and communities whose belligerency has been recognized.70 Limitations upon independence may arise from special treaties with certain powers, as in the relationships established between the United States and Cuba, ${ }^{71}$ the Dominican Republic, ${ }^{72} \mathrm{Hayti}^{78}$ Nicaragua, ${ }^{74}$ and Panama ${ }^{75}$ respectively. Or they may be created by the provisions of general treaties like the Vienna Congress Treaty of $1815{ }^{76}$ the Treaty of Paris of $1856,{ }^{77}$ or the Treaty of Berlin of $1878 .{ }^{78}$ They may be the result of an international agreement such as that embodied in the treaties of 1839 guaranteeing Belgian neutrality, ${ }^{78}$ the treaty of 1867 neutralizing Luxemburg, ${ }^{80}$ or the conventions of 1907 establishing the Central

\footnotetext{
${ }^{e x}$ See G. F. de Martens, Précis de droit des gens moderne de l'Europe (ed. by Vergé, Paris, 1858) Introd., secs. 6-9; Bk. I, chap. 2; Bk. IV, chap. $x$, sec. II9; and passim; and Moser, Versuch des neuesten Europäischen Völkerrechts in Friedens-und Kriegsaeiten (Frankfort-on-the-Main, I777-80), Pt. I, Bk. I, chaps. I and 2.

${ }^{\oplus}$ Op. cit., Vol. I, p. 21.

${ }^{70}$ Ibid., Vol. I, chap. 3.

${ }^{n}$ Malloy, Treaties, Conventions, etc. (Washington, rgro) Vol. I, pp. $362-364$.

${ }^{72}$ Ibid., Vol. I, pp. 418-420.

73 (igi6) io AM. JoUr. Int. LAw, Supp. 234-238.

"Ibid., pp. 258-260.

"Malloy, op. cit., Vol. II, pp. 1349-1357.

${ }^{76}$ Hertslet, Map of Europe by Treaty (London, 1875-9I) Vol. I, pp. 208-277.

"Ibid., Vol. II, pp. 1250-1265.

${ }^{78}$ Ibid., Vol. IV, pp. 2759-2799.

${ }^{79}$ Ibid., Vol. II, pp. 979-998.

${ }^{80}$ Ibid., Vol. III, pp. 180I-I805.
} 
American Court of Justice. ${ }^{81}$ The legal significance of such restrictions upon independence has been admitted by most of the writers. It may prove necessary to give legal recognition to varying degrees of independence resulting from the political activities of the Great Powers, such as the hegemony of the Great Powers in Europe, of the United States in the western hemisphere, or of a League of Nations after the present war. Writers generally have denounced differences of this kind as purely political and without any foundation in international law ; but it is not at all certain that international law can continue to blink at realities in this respect. ${ }^{83}$ It is conceivable that we may find it desirable to accord legal recognition to other de facto differences affecting the independence of international persons. There is strong prejudice against admitting anything that involves the recognition of new degrees of status in the law of nations. It is sometimes pointed out that the whole progress of municipal law has been from status to contract. This is true. We must remember however that international law is still in a very rudimentary stage of development, and that its subjects are persons of an entirely different nature, admitting of entirely different diversities. Degrees of independence must inevitably give rise to differences of status for which there are no satisfactory analogues in municipal law.

No profitable comparison can be drawn between the factors contributing to differences of status in municipal law and in the law of nations. ${ }^{84}$ Status in municipal law is either normal or abnormal. Normal status is the legal character of the great body of citizens for whom the general laws are made and to whom in their full scope and meaning they are applied. Abnor-

\footnotetext{
8a (Ig08) 2 Am. Jour. INT. LAw, SUPP. 219-243.

$\approx$ E. g., see Nys, Etudes de droit international et de droit politique (Paris, Igor) Vol. II, pp. 44-46; Oppenheim, op. cit., Vol. I, pp. I70-I7I; and Rivier, Principes du droit des gens (Paris, I896) Vol. I, p. I25.

\& See Funck-Brentano et Sorel, Précis du droit des gens (3d ed., Paris, I900) p. 46; Lawrence, op. cit., Essay V; Lawrence, Principles of International Laze (5th ed., New York, rgr3) chap. 4; Lorimer, Institutes of the Law of Nations (London, I883-84) Vol. I, Bk. II, chaps. I5 and 16; Westlake, op. cit., Vol. I, pp. 322-323.

${ }^{84}$ The subject of status in municipal law is discussed in Austin, Lectures on Jurisprudence (4th ed., London, I873) Vol. II, pp. 705 ff.; Holland, Jurisprudence, pp. 340-346 and passim; Markby, Elements of Law (3d ed., Oxford, 1885) secs. 168-180 and 300 .
} 
mal status is the legal character of those peculiar classes who for one reason or another are regarded as improper subjects for the application of the general laws and therefore are exempted to a greater or less extent from their operation. The chief varieties of abnormal status among natural persons may be referred, according to Holland, to (I) sex, (2) minority, (3) patria potestas and manus, (4) coverture, (5) celibacy, (6) mental defect, (7) bodily defect, (8) rank, caste, and official position, (9) race and color, (IO) slavery, (II) profession, (I2) civil death, (I3) illegitimacy, (I4) heresy, (I5) foreign nationality, and (I6) hostile nationality. ${ }^{85}$ Among international persons status rests upon factors of an entirely different kind. Some of the factors have received reluctant recognition from the publicists, and some have been neglected. The whole subject has been treated in a very unsatisfactory manner and in a few instances virtually denied altogether. ${ }^{86}$ This is chiefly because the writers have failed to look beyond the artificial personality of the state to its essential elements and the realities of its relations with other states. Until international law is accommodated to the peculiar character of its subjects it can never be placed upon a thoroughly scientific basis. This will hardly be hastened by continuing to stress the analogy between international persons and human beings.

Defects in the analogy are in no wise exhausted by a comparison of the elements essential to the existence of an international person with the elements of natural existence. If we compare natural and international persons with respect to their creation, continuous existence, and extinction, the utter lack of any real resemblance is equally striking. Human beings are physical entities created by the natural processes of reproduction. International persons are corporate entities created by the voluntary subdivision of an existing international person, by the voluntary combination of existing international persons, by a general agreement enforced by the Great Powers, by separation as the result of a successful insurr ection, by the recognition of a country previously denied admission into the international society, or by the erection of a new international person in a region previously uncivilized. The continuous existence of a natural person

${ }^{85}$ Op. cit., p. 340.

${ }^{85}$ Lorimer is one of the few writers who seems to have appreciated the importance of the subject. See op. cit., Vol. I, Bk. II, chap. I5. 
depends upon the continuation of physical life. Human beings are mortal. The continuous existence of an international person depends upon the continuation in the necessary coördination of the several elements essential to its existence, the elements being those already enumerated and discussed. The international person is immortal. Important changes may occur in an international person's population, territory, government, or even in the degree of its independence, and yet it may continue to be a person in international law. An international person cannot be permanently deprived of any of these elements and continue in existence, while a natural person may be deprived of both liberty and possessions and continue to live. On the other hand, an international person may survive an abnormal condition, like the military occupation of Belgium, Servia, or Luxemburg, and not only continue to live, but continue capable of assuming obligations and asserting rights. Finally, while natural persons cease to exist only on physical death, the extinction of international persons may be the result either of voluntary arrangement or of conquest. It may be the consequence of the reverse of any of the processes of creation named above. The consequences of extinction are fundamentally different in the case of human beings and of states. It is the merest sophistry to say that "as individual human beings are born, attain the age of majority, and die, so States come into existence, obtain full international recognition, and cease to be."

Human beings differ fundamentally from states in respect to their faculty of choosing or their will. Westlake says that we are accustomed to think of the international person as "having a responsibility and a conscience which are the summation of the responsibilities and consciences of its members." ${ }^{87}$ This is of course a dogmatic fiction.

"In every aggregation of men there are some of the number who impress their wills upon the others, who are habitually obeyed by the others, and who are, in truth, the rulers of the society. The sources from which their authority flows are of the most diverse character. They may be, or may pretend to be, divinely inspired. It may be their physical strength, their wisdom, their cunning, their virtues, their vices, - oftenest, perhaps, their assiduity and persistence,- that have given them their power. The sources of this power are, indeed, so various, and its

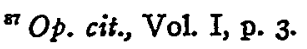


mode of action so subtle and often unknown even by those who exercise it, that it is impossible to define or closely trace it."ss

The fiction should never be abused by attempting to apply to international persons standards of conduct or the like suited only for the subjects of municipal law. This tendency to regard international persons as if they were individuals with a conscience, a sense of honor, a single interest, and a single life, confuses our thinking. When we attempt to attribute to them rights and duties copied from the rights and duties of human beings living under municipal law we are simply injecting ourselves into a world of fictions wherein the necessities of international relationships are bound to be obscured.

There are grave possibilities in the abuse of the analogy in the future. Radical suggestions are being offered for the amendment of international law, many of them of a constructive character. It has been ably argued for example that if the law of nations is to have a real binding force there must be a change in its theory, and violations of such a character as to threaten the peace and order of the international community must be deemed to be in violation of the right of every member of that community to have the law maintained and a legal injury to every member. ${ }^{89}$ Progress along these lines may be misdirected and defeated if we attempt merely to engraft principles of criminal law and procedure upon the law of nations. There is a widespread opinion that the constant menace of war can be mitigated only by the further perfection of international organization. One of the greatest obstacles to progress in this direction will be found in the tendency to personify international persons and attribute to them rights derived from the analogy with human beings. The so-called rights of existence, independence, equality, and property, as hitherto construed by a majority of the writers, are likely to prove an insuperable obstacle to real progress in the direction of international government.

It has been no part of my purpose to belittle the usefulness of municipal law in the development of the international system.

\footnotetext{
${ }^{89} \mathrm{Gray}$, op. cit., sec. I53. Interesting light is thrown upon this question by such a book as Michels, Political Parties, a sociological study of the oligarchical tendencies of modern democracy (New York, IgI5).

${ }^{8}$ Root, The Outlook for International Law (Igr6) Io AM. Jour. INT. LAW, I-II.
} 
Some of the earlier stages in the growth of that system were assisted incalculably by borrowed principles. There are no doubt principles of jurisprudence that are fundamental to all legal systems, whatever the nature of their subjects. It has been my purpose to urge that the analogy between natural and international persons must be used, if at all, with much greater discrimination in the future. It must not be permitted to warp our conception of international society, obstruct an understanding of the true nature of international persons, perpetuate the unreality of international law, encumber the system with rules inapplicable to international persons, or establish impractical classifications. If the law of nations is ever to become more than "the vanishing point of jurisprudence" it must be accommodated to the peculiar nature of its subjects.

Edwin DeWitr Dickinson.

\section{Daztmouth College.}

